\title{
Sulfonamide resistance genes in soils treated with waste from animal production in an organic production system
}

\section{Genes de resistência a sulfonamida em solos tratados com resíduos da produção animal em sistema orgânico de produção}

Camila Costa de Oliveira'; Danielli Monsores Bertholoto2; Elisamara Caldeira do Nascimento3; Everaldo Zonta4; Shana de Mattos de Oliveira Coelho ${ }^{5}$; Miliane Moreira Soares de Souza5; Paulo Regis Bandeira de Melo6; Irene da Silva Coelho ${ }^{7 *}$

\section{Highlights}

Animal waste is a source of sulfonamide resistance genes sul1 and sul2.

Composting process may not be enough to eliminate antimicrobial resistance genes.

Animal waste can increase genes for resistance to antimicrobials in agricultural soils.

\begin{abstract}
Animal waste is widely used in organic production systems. However, these residues can increase antimicrobial determinants in the soil. In this perspective, this study was developed to evaluate the presence of sulfonamide resistance genes in soils from an organic production system that received animal waste as organic fertilizer. Soil samples were collected from four properties with different management practices to increase soil fertility. Three properties use the animal waste from the conventional system and the other use plant residues as soil cover and a legal reserve. The extraction of total DNA from soil was carried out followed by the amplification of genes encoding sulfonamide resistance (su/1 and su/2) by the PCR (polymerase chain reaction) technique. The sul1 and sul2 genes were detected only in soils treated with animal waste. The

1 M.e in Agronomy Soil Science, Federal Rural University of Rio de Janeiro, UFRRJ, Seropédica, RJ, Brazil. E-mail: camila.costadeo@gmail.com

2 Student of the Doctoral Course of Graduate Program in Science Technology and Innovation in Agriculture, UFRRJ, Seropédica, RJ, Brazil. E-mail: daniellibertholoto@yahoo.com.br

3 Ph.D. in Agronomy Soil Science, UFRRJ, Seropédica, RJ, Brazil. E-mail:elisamara.caldeira@gmail.com

4 Prof. Dr., Department of Crop Science, Institute of Agronomy, UFRRJ, Seropédica, RJ, Brazil. E-mail: ezonta@ufrrj.br

5 Profs. Drs., Department of Microbiology and Veterinary Immunology, Institute of Veterinary, UFRRJ, Seropédica, RJ, Brazil. E-mail: shana_mattos@hotmail.com; milianemss@gmail.com

${ }^{6}$ Prof. Dr., Institute Federal Sudeste of Minas Gerais, IFSUDESTEMG, Rio Pomba, MG, Brazil. E-mail: paulo.melo@ ifsudestemg.edu.br

7 Profa Dra, Department of Microbiology and Veterinary Immunology, Institute of Veterinary, UFRRJ, Seropédica, RJ, Brazil. E-mail: irenecs@yahoo.com

* Author for correspondence
\end{abstract}

Received: July 19, 2020 - Approved: Mar. 19, 2021 
genes were not detected in soils from the legal reserve and the property that used plant residues as soil cover. These results indicate that the use of animal waste as agricultural fertilizer can increase genes for resistance to antimicrobials in the soil and the composting process may not be enough to eliminate them. This information reiterates the need to implement standards that establish quality parameters for animal waste, considering resistance to antimicrobials, as well as the development of management strategies that reduce the risk of spreading resistance to antimicrobials when these residues are applied to soils.

Key words: Animal waste. Antimicrobial resistance. Bovine manure. Poultry litter.

\section{Resumo}

Resíduos animais são amplamente utilizados em sistemas de produção orgânicos. No entanto, esses resíduos podem incrementar determinantes antimicrobianos no solo. Nesta perspectiva, este estudo foi desenvolvido para avaliar a presença de genes de resistência à sulfonamida em solos do sistema de produção orgânico que receberam resíduos de animais como fertilizante orgânico. Amostras de solo foram coletadas de quatro propriedades com diferentes formas de manejo para aumentar a fertilidade do solo. Três utilizaram resíduos animais do sistema convencional; uma utilizou resíduos vegetais como cobertura do solo, além de uma reserva legal. Foi realizada a extração do DNA total do solo, seguida da amplificação dos genes que codificam resistência sulfonamida (sul1 e sul2) pela técnica de PCR (Polymerase Chain Reaction). Os genes sul1 e sul2 foram detectados apenas nos solos tratados com dejetos de animais. Não foram detectados nos solos da reserva legal e das propriedades que utilizavam resíduos vegetais como cobertura do solo. Esses resultados indicam que o uso de resíduos animais como fertilizante agrícola pode incrementar genes de resistência aos antimicrobianos no solo e que o processo de compostagem pode não ser suficiente para eliminá-los. Essas informações reiteram a necessidade de implementar padrões que estabeleçam parâmetros de qualidade para os resíduos animais, levando em conta a resistência aos antimicrobianos, bem como o desenvolvimento de estratégias de manejo que reduzam o risco de disseminação da resistência aos antimicrobianos quando esses resíduos são aplicados no solo.

Palavras-chave: Resíduos animais. Resistência a antimicrobianos. Esterco bovino. Esterco de galinha.

Animal wastes are widely used in organic production systems to provide nutrients to crops and promote soil attributes due to organic matter addition (Blum et al., 2006). This practice is in line with Federal Law No. 10,831/2003, which recommends the recycling of organic waste to minimize the use of non-renewable resources in organic production systems (Lei 10.831, 2003).

According to Normative 64/2008, which decides on the organic systems of animal and plant production, the residue that contains animal excrements must be composted and bio-stabilized to be applied as fertilizer. Also, it is recommended that the residues come from animals managed in organic systems. The use of animal waste produced conventionally is allowed when organic animal waste is not available in the region, provided that, in addition to being composted, it does not exceed the maximum limit allowed for contaminants, such as heavy metals and some pathogens (Instrução Normativa n 64, 2008).

Animal treatment with antimicrobials is prohibited in the organic animal production system. It is only allowed in cases of illnesses 
or injuries in which the use of the permitted medicines is not effective and the animal presents suffering or risk of death. If applied, the waste from these animals during the treatment and grace period cannot be sold or used as organic (Instrução Normativa nº 64, 2008). However, antimicrobials are commonly used in conventional production systems for therapeutic and prophylactic purposes or as zootechnical additives added to the diets at therapeutic and subtherapeutic doses for almost the entire life of the animal to accelerate weight gain and increase feed efficiency (Thomas et al., 2015). A large proportion of the administered antimicrobials is usually excreted as an unchanged substance or as metabolites that may still be active, which favors the selection of the antimicrobial resistance of bacteria present in the feces of these animals (Zhu et al., 2013). Thus, despite the benefits obtained with the use of animal waste in agricultural environments, these compounds can be a source of antimicrobials, bacteria resistant to antimicrobials, and antimicrobial resistance genes (Reginato \& Leal, 2010).

Soil represents a natural reservoir of bacteria resistant to antimicrobials, carrying a diverse set of known and unknown determinants of resistance. However, activities that release resistant antimicrobials and/or antimicrobial-resistant bacteria, and/or antimicrobial resistance genes, such as animal manure applications as organic fertilizer, can increase the abundance and diversity of resistance genes intrinsic to the soil, affect its resistome, and favor the dissemination of determinants of antimicrobial resistance to commensal bacteria and pathogens of humans and animals (Xie, Shen, \& Zhao, 2018). Therefore, this study aimed to evaluate the presence of genes of resistance to sulfonamide sul1 and sul2 in soils from properties with different management practices to increase soil fertility.

The study was conducted on properties that adopt the organic production system, located in the municipality of Seropédica, Rio de Janeiro, Brazil. The properties belong to producers associated with the Participatory Guarantee System-ABIO (SPG-ABIO), Seropédica Nucleus - RJ. According to Law N ${ }^{\circ}$ $12,651 / 2012$, all rural properties must maintain an area covered with native vegetation, named as a legal reserve.

The main soil classes identified in the municipality of Seropédica are Red-Yellow Argisols, Haplic Planosols, and Haplic Gleysols (Ramos, Castro, \& Camargo, 1973). The first two soil classes occur in a larger extension in the region, being those of higher agricultural use.

Soil samples were collected from four properties with different management practices to increase soil fertility (Table 1). Cattle and chicken manure were acquired in properties that adopt the conventional production system, being previously composted before the incorporation into the soil. Two samples were collected from each property. A soil sample from the legal reserve was also collected in the fourth property for comparative purposes, totaling nine soil samples for analysis. Each sample consisted of a composite sample prepared from three simple samples, collected at a depth of 0-5 $\mathrm{cm}$. The soils were characterized according to their physical and chemical characteristics, following the methodology described by Donagema, Campos, Calderano, Teixeira and Viana (2011). 
Table 1

Types of management used to increase soil fertility and identification of the collected samples

$\begin{array}{ccc}\text { Property } & \text { Type of management } & \text { Identification } \\ 1 & \text { Plant residues covering the soil } & \text { P1A } \\ & & \text { P1B } \\ 2 & \text { Limestone, natural phosphate, "Yorin" phosphate fertilizer, and cattle manure } & \text { P2A } \\ & \text { P2B } \\ 3 & \text { Limestone, natural phosphate, and cattle and chicken manure } & \text { P3A } \\ & \text { Natural phosphate and chicken and cattle manure } & \text { P3B } \\ 4 & \text { Legal reserve } & \text { P4A } \\ 4 & & \text { LR }\end{array}$

The soil samples were processed (airdried and sieved in a $2.0-\mathrm{mm}$ diameter mesh) to determine the contents of organic matter (OM), $\mathrm{pH}\left(\mathrm{H}_{2} \mathrm{O}\right), \mathrm{P}, \mathrm{K}, \mathrm{Ca}, \mathrm{Mg}$, exchangeable $\mathrm{Al}, \mathrm{H}+\mathrm{Al}$, sum of bases, sand, silt, and clay, according to Embrapa methodology (Donagema et al., 2011). The physicochemical characterization isshown in Table 2.

The extraction of total DNA from the soil was performed using the Power Soil DNA Isolation kit (MOBIO Laboratories, Inc, USA), according to the protocol provided by the manufacturer. The quantity and quality of the DNA obtained were evaluated using a NanoDrop ND-1000 spectrophotometer (Thermo Fisher Scientific, USA). The DNA integrity was assessed by electrophoresis on $0.8 \%$ agarose gel plus SYBR green (Invitrogen, USA). The gel was visualized under $254 \mathrm{~nm}$ UV light and the images were captured using the L-PIX EX photo-documentation system (Loccus Biotechnology, Brazil).

The PCR (polymerase chain reaction) was performed in a $20-\mu \mathrm{L}$ volume containing $1 \mathrm{X}$ of reaction buffer, $2.5 \mathrm{mM} \mathrm{MgCl}_{2}$ (Invitrogen,
USA), $0.2 \mathrm{mM}$ of each dNTP (Invitrogen, USA), $0.4 \mu \mathrm{M}$ of each primer (Invitrogen, USA), $1 U$ of Taq DNA polymerase (Invitrogen, USA), and $10-30 \mathrm{ng}$ of DNA. Primers 27-F (5'-AGAGTTTGATCCTGGCTCAG-3') (Suzuki \& Giovannoni, 1996) and 1512-R (5'-ACGGCTACCTTGTTACGACT-3') (Kane etal., 1993) were used in the amplification of the rrs gene encoding the $16 S$ rDNA. Primers sul1-F (5'-CGCACCGGAAACATCGCTGCAC-3') and sul1-R (5'-TGAAGTTCCGCCGCAAGGCTCG-3') and sul2-F (5'-TCCGGTGGAGGCCGGTATCTGG-3'), and sul2-R (5'-GGGAATGCCATCTGCCTTGAG-3') (Pei, Kim, Carlson, \& Pruden, 2006) were used in the amplification of genes related to sulfonamide resistance. Amplifications of the rrs gene were carried out according to the following parameters: $5 \mathrm{~min}$ of initial denaturation at $94{ }^{\circ} \mathrm{C}, 30$ cycles of $94{ }^{\circ} \mathrm{C}$ for $60 \mathrm{~s}, 58^{\circ} \mathrm{C}$ for $60 \mathrm{~s}, 72{ }^{\circ} \mathrm{C}$ for $60 \mathrm{~s}$, followed by a final elongation at $72{ }^{\circ} \mathrm{C}$ for $10 \mathrm{~min}$. The amplification conditions of the sul 1 and sul2 genes were optimized: $5 \mathrm{~min}$ of initial denaturation at $95{ }^{\circ} \mathrm{C}, 40$ cycles of $95{ }^{\circ} \mathrm{C}$ for $30 \mathrm{~s}, 60^{\circ} \mathrm{C}$ for $30 \mathrm{~s}, 72{ }^{\circ} \mathrm{C}$ for $30 \mathrm{~s}$, followed by a final elongation at $72{ }^{\circ} \mathrm{C}$ for $7 \mathrm{~min}$. The 


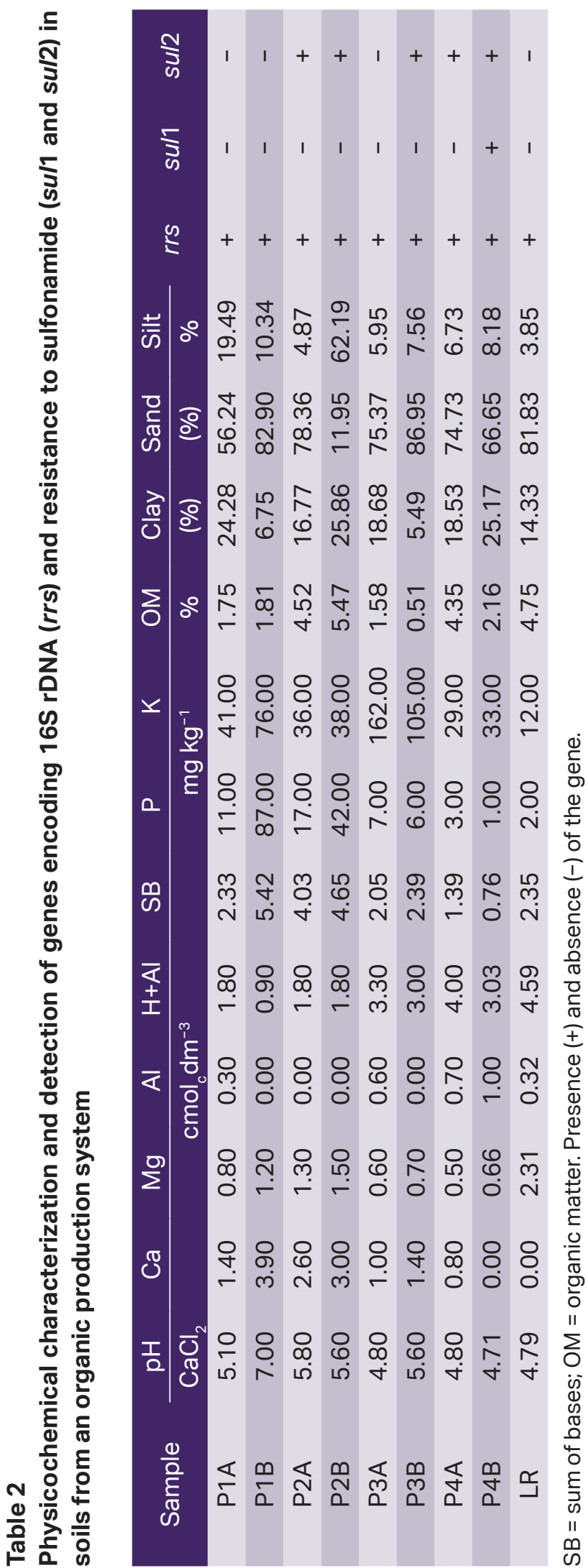

products of PCR reactions were visualized by electrophoresis on a $1.5 \%$ agarose gel under UV light in the photo documentation system L-PIX EX (LoccusBiotechnology, Brazil). All reactions were performed in triplicates to confirm the results. The positive control of PCR reactions was obtained by extracting DNA from a sulfonamide-resistant strain of Escherichia coli isolated from chickens from poultry farms located in the state of Rio de Janeiro (Pimenta, 2018).

The organic management of soils in the evaluated properties is inefficient to maintain soil fertility at adequate levels, especially regarding the neutralization of $\mathrm{Al}^{3+}$, which is toxic to plants, and the maintenance of the $\mathrm{pH}$ around 6.5 (Table 2). The liming process is fundamental for any agricultural production system. It is the most efficient way to increase the soil $\mathrm{pH}$ and, consequently, decrease the $\mathrm{Al}^{3+}$, in addition to increasing soil Ca and Mg contents (Barbosa \& Silva, 1994; Caires, Kusman, Barth, Garbuio, \& Padilha, 2004). Under Brazilian Legislation (Lei 10.831, 2003), organic production systems can use commercial fertilizers if they are poorly soluble and hence nutrients are made available to the soil gradually and slowly. However, we can observe that the properties that use natural phosphate with phosphorus source (P3 and $\mathrm{P} 4)$ have this nutrient well below that of the others. Moreover, the organic matter content was higher than $1.5 \%$ in all areas and, for some samples, the levels were higher than the control (4.75\%). It indicates an improvement in soil quality and process restoration of agroecosystems (Faucon, Houben, \& Lambers, 2017), mainly due to plant biodiversity (recommended in organic systems) and fertilization with organic residues (manure). 
The rrs gene encoding 16S rDNA was detected in all soil samples (Table 2), confirming there is DNA in sufficient quantity and quality to be used as a template for PCR amplification of genes encoding antimicrobial resistance. The sul1 gene, encoding sulfonamide resistance, was detected in only one soil sample from property 4, in which bovine manure was used, representing $11 \%(1 / 9)$ of the samples. The sul2 gene was detected in 55\% (5/9): in both samples from property 2 and 4, which used bovine manure as fertilizer, and also in a sample from property 3 , where bovine and chicken manure were used as fertilizer. Neither gene was detected in soils from property 1 , which use plant residues covering the soil, and in the legal reserve area (Table 2).

Independent cultivation techniques based on nucleic acids have been increasingly used in environmental microbiology studies, as they allow reaching a larger portion of the bacterial community in their natural habitat since cultivable microorganisms represent less than $1 \%$ of the microbial population in the soil (Amann, Ludwig, \& Schleifer, 1995). We can extrapolate this advantage to studies of antimicrobial resistance, in which we have access to antimicrobial resistance genes directly from DNA of a wider range of soil bacteria and not only those grown in the culture medium.

Soils from four properties under the organic system and a legal reserve in the municipality of Seropédica-RJ were analyzed to evaluate the presence of sulfonamide resistance genes (su/1 and sul2). Sulfonamides were the first antimicrobials used systematically to prevent and treat diarrhea and other infectious diseases (Heuer \& Smalla, 2007). The action of this drug is related to the inhibition of the formation of dihydrofolic acid by binding to the enzyme dihydropteroate synthase (DHPS) in the folic acid pathway. Bacterial resistance to sulfonamides mainly occurs because of mutations in the DHPS gene (fo/P) or due to the acquisition of alternative DHPS genes sul1, sul2, and sul3 (Sköld, 2000). Property 1 , where only plant residues are used in the soil cover, as well as the legal reserve area, did not present any of the two evaluated resistance genes, which suggests that the resistance genes detected in properties 2, 3, and 4 come from animal residues applied as organic fertilizers in the soils. The difference in animal waste used as organic fertilizers in the properties analyzed in this study ( 2 and 3 - cattle manure; 4 - cattle and chicken manure) can reflect the increase of different genes in soils, as the sul1 gene was detected only on property 4 and sul 2 was detected on properties 2, 3, and 4.

Soils have a high abundance of microorganisms and represent a large natural reservoir of antimicrobial resistance genes. Although the sul1 and sul2 genes have not been detected in the legal reserve area, there is evidence that genes from antimicrobial resistance are originated in the environment even before the use of antimicrobial by humanity (Wright, 2007; Xie et al., 2018).

Studies have shown that sulfonamide resistance genes are often detected in manure and soil fertilized with manure, and the frequency in which they are found is closely related to the frequency in which they are used (Lin et al., 2016). There is a lower occurrence of resistance genes in bovine manure compared to chicken manure (Wichmann, Udikovic-Kolic, Andrew, \& Handelsman, 2014). This variation occurs due to differences in management practices, in which antimicrobials are used less frequently in cattle production for the 
prevention and treatment of diseases. At the same time, it is added to the feed as a zootechnical additive in poultry farming, besides its prophylactic and therapeutic use, resulting in approximately four times more antimicrobials for chicken production compared to cattle (Kim et al., 2011).

The current legislation allows the use of animal waste from conventional production in organic production systems, when organic animal waste is no available in the region as is the case of the studied properties (Instrução Normativa $n^{\circ} 64,2008$ ). The use of antimicrobials in the organic animal production system is prohibited and they can only be used when the treatment with permitted medicines is not effective, the animal is suffering, or is at risk of death. In this case, a grace period is imposed during and after treatment so that products, by-products, and manure from these animals are not sold or used as organic (Instrução Normativa nº 64, 2008).

Studies demonstrating the occurrence of resistance genes on agricultural soils are scarce. In Brazil, most studies are related to aquatic environments (Serafim \& Ruiz, 2018). However, Cadena et al. (2018) conducted a study with soil from organic production systems treated with organic animal residues in Nebraska to evaluate the presence of genes for resistance to tetracycline and sulfonamide in these environments and found that about $93 \%$ of the analyzed soil samples (182/196) of 12 organic properties showed resistance genes to these antimicrobials. Antimicrobial resistance genes are also present in bacteria in the intestinal tract of animals not treated with antimicrobials. They confer an intrinsic resistance, that is, the organism is not susceptible to the compound due to an inherent structural or functional characteristic
(Heuer \& Smalla, 2007). Thus, residues from organic or conventional animal production can carry resistance genes and management techniques that aim to eliminate these genes must be used to avoid contamination of the environment.

Composting is alternative management that can result in the reduction or elimination of undesirable pathogens of animal residues. Composting consists of an aerobic process by which several groups of microorganisms break down organic materials and produce stable organic and inorganic products. During this process, the intense proliferation of microorganisms causes an increase in temperature capable of destroying pathogens and guaranteeing the final product (Orrico, Orrico, \& Lucas, 2009). However, there is still no consensus on its effect on the elimination of antimicrobial residues and particularly antimicrobial resistance genes, which can vary depending on the type of material of animal origin and the conditions of the composting procedure (Maccari, Segat, Testa, MalucheBaretta, \& Baretta, 2020).

Lin et al. (2017) investigated the effect of different temperatures in the composting process of swine and chicken manure on the degradation of sulfonamide, resistant bacteria, and resistance genes for this antimicrobial and observed an efficient degradation in chicken manure for the antimicrobial at a temperature of $30{ }^{\circ} \mathrm{C}$, different from the result of swine manure, which had a higher degradation efficiency at thermophilic temperatures (above $60{ }^{\circ} \mathrm{C}$ ). However, no incubation effectively decreased the relative abundance of sul1 and sul 2 resistance genes and resistant bacteria in the animal waste. It highlights the varied effects of composting on the different contaminants present in the 
substrate, being dependent on the conditions and materials used in the process. According to Qian et al. (2016), the composting process was efficient in decreasing the abundance of genes resistant to tetracyclines, that is, tetQ, tet $\mathrm{M}$, and tetW, in bovine manure. However, it increased the abundance of tet $\mathrm{C}$, tet $\mathrm{X}$, sul1, and sul2.

The animal waste used in organic production properties in this study came from a conventional system, being previously composted before the incorporation into the soils. Thus, the results shown in this study corroborate the hypothesis that using animal manure as a fertilizer in agricultural soils can be a source of resistance genes. It also reinforces the need for management strategies that effectively reduce the risk to spread antimicrobial resistance in agricultural environments and the implementation of standards that establish animal waste quality parameters to be applied safely in organic production.

This study showed that the use of animal residues from conventional production, though composting, may favor the occurrence of sulfonamide resistance genes in soils from an organic production system.

\section{Acknowledgments}

Wethank the following research funding agencies for financial support: CNPq (National Council for Scientific and Technological Development), CAPES (Coordination for the Improvement of Higher Education Personnel), and FAPERJ (Fundação Carlos Chagas Filho de Amparo à Pesquisa do Estado do Rio de Janeiro).

\section{References}

Amann, R. I., Ludwig, W., \& Schleifer, K. H. (1995). Phylogenetic identification and in situ detection of individual microbial cells without cultivation. Microbiology and Molecular Biology Reviews, 59(1), 143-169. doi: 10.1128/mmbr.59.1.143-169.1995

Barbosa, M. P., F., Silva, O. F.(1994). Aspectos agro-econômicos da calagem e da adubação nas culturas de arroz e feijão irrigados. Pesquisa Agropecuária Brasileira, 29(11), 657-1667.

Blum, L. E. B., Amarante, C. V. T., Güttler, G., Macedo, A. F., Kothe, D. M., Simmler, A. O., Prado, G. \& Guimarães, L. S. (2006). Produção de moranga e pepino em solo com incorporação de cama aviária e casca de pinus. Horticultura Brasileira, 21(4), 627-631. doi: 10.1590/S0102-0536 2003000400010

Cadena, M., Durso, L. M., Miller, D. N., Waldrip, H. M., Castleberry, B. L., Drijber, R. A., \& Wortmann, C. (2018). Tetracyclineand sulfonamide antibiotic resistance genes in soils from Nebraska organic farming operations. Frontieres in Microbiology, 9, 1283. doi: 10.3389/fmicb.2018.01283

Caires, E. F., Kusman, M. T., Barth, G., Garbuio, F. J., \& Padilha, J. M. (2004). Alterações químicas do solo e resposta do milho à calagem e aplicação de gesso. Revista Brasileira de Ciência do Solo, 28(1), 125136. doi: $10.1590 / S 0100-06832004000$ 100013

Donagema, G. K., Campos, D. V. B., Calderano, S. B., Teixeira, W. G., \& Viana, J. H. M. (2011). Manual de métodos de análises 
de solos (2a ed. rev.). (EMBRAPA Solos, Documentos, 132). Rio de Janeiro: EMBRAPA Solos.

Faucon, M., Houben, D., \& Lambers, H. (2017). Plant functional traits: soil and ecosystem services. Trends Plant Science, 22(5), 385394. doi: 10.1016/j.tplants.2017.01.005

Heuer, H., \& Smalla, K. (2007). Manure and sulfadiazine synergistically increased bacterial antibiotic resistance in soil over at least two months. Environmental Microbiology, 9(3), 657-666. doi: 10.1111/j. 1462-2920.2006.01185.x

Kane, D. J., Sarafian, T. A., Anton, R., Hahn, H., Gralla, E. B., Valentine, J. S., \& Bredesen, D. E. (1993). Bcl-2 inhibition of neural death: decreased generation of reactive oxygen species. Science, 262(5137), 1274-1277. doi: 10.1126/science.8235659

Kim, K. R., Owens, G., Kwon, S. I., So, K. H., Lee, D. B., \& Ok, Y. S. (2011). Occurrence and environmental fate of veterinary antibiotics in the terrestrial environment. Water, Air, \& Soil Pollution, 214(1-4), 163174. doi: 10.1007/s11270-010-0412-2

Instrução Normativa $n^{\circ} 64$, de 18 de dezembro de 2008. Aprova o regulamento técnico para os sistemas orgânicos de produção animal e vegetal. Recuperado de http:// www.gov.br/agricultura/pt-br/assuntos/ vigilancia-agropecuaria/ivegetal/bebidasarquivos/in-no-64-de-18-de-dezembrode-2008.pdf/view

Lei 10.831, de 23 de dezembro de 2003. Dispõe sobre a agricultura orgânica e dá outras providências. Recuperado de http:// www.planalto.gov.br/ccivil_03/Leis/2003/ L10.831.htm
Lin, H., Sun, W., Zhang, Z., Chapman, S. J., Freitag, T. E., Fu, J., Zhang, X., \& Ma, J. (2016). Effects of manure and mineral fertilization strategies on soil antibiotic resistance gene levels and microbial community in a paddy-upland rotation system. Environmental Pollution, 211,332337. doi: 10.1016/j.envpol.2016.01.007

Lin, H., Zhang, J., Chen, H., Wang, J., Sun, W., Zhang, X., \& Ma, J. (2017). Effect of temperature on sulfonamide antibiotics degradation, and on antibiotic resistance determinants and hosts in animal manures. Science of the Total Environment, 607,725732. doi: 10.1016/j.scitotenv.2017.07.057

Maccari, A. P., Segat, J. C., Testa, M., MalucheBaretta, C. R. D., \& Baretta, D. (2020). The effect of composted and non-composted poultry litter on survival and reproduction of folsomia candida. International Jornal of Recycling of Organic West in Agriculture, 9(1), 99-105. doi: 10.30486/ IJROWA.2020.1885804.1012

Orrico, M. A. P. Jr., Orrico, A. C. A., \& Lucas, J., Jr. (2009). Compostagem da fração sólida da água residuária de suinocultura. Engenharia Agrícola, 29(3), 483491. doi: 10.1590/S0100-69162009000300015

Pei, R., Kim, S. C., Carlson, K. H., \& Pruden, A. (2006). Effect of river landscape on the sediment concentrations of antibiotics and corresponding antibiotic resistance genes (ARG). Water Research, 40(12), 24272435. doi: 10.1016/j.watres.2006.04.017

Pimenta, R. L. (2018). Avaliação da resistência antimicrobiana e da virulência em cepas bacterianas isoladas de aves em estabelecimentos de corte e postura no estado do Rio de Janeiro. Tese de doutorado, Universidade Federal Rural do Rio de Janeiro, Seropédica, RJ, Brasil. 
Qian, X., Sun, W., Gu, J., Wang, X. J., Sun, J. J., Yin, Y. N., \& Duan, M. L. (2016). Variable effects of oxytetracycline on antibiotic resistance gene abundance and the bacterial community during aerobic composting of cow manure. Journal of Hazardous Materials, 315, 61-69. doi: 10.1016/j.jhazmat.2016.05.002

Ramos, D. P., Castro, A. F., \& Camargo, M. N. (1973). Levantamento detalhado de solos da área da Universidade Federal Rural do Rio de Janeiro. Pesquisa Agropecuária Brasileira, 8, 1-27.

Reginato, J. B., \& Leal, R. M. P. (2010). Comportamento e impacto ambiental de antibióticos usados na produção animal brasileira. Revista Brasileira de Ciência de Solo, 34(3), 601-616. doi: 10.1590/S010006832010000300002

Serafim, V. J., \& Ruiz, L. G. P. (2018). Genes bacterianos de resistência no meio ambiente. Revista Científica, 1(1), 1-10. Recuperado de http://189.112.117.16/ index.php/revista-cientifica/article/ view/103

Sköld, O. (2000). Sulfonamide resistance: mechanisms and trends. Drug Resistance Updates, 3(3), 155-160. doi: 10.1054/drup. 2000.0146

Suzuki, M. T., \& Giovannoni, S. J. (1996). Bias caused by template annealing in the amplification of mixtures of 16S rRNA genes by PCR. Applied and Environmental Microbiology, 62(2), 625-30. doi: 10. 1128/ AEM.62.2.625-630.1996
Thomas, P. Boeckel V., Brower, C., Gilbert, M., Bryan, T., Grenfell, S. A., Levin, Timothy, P. R., Teillant, A., \& Laxminarayan, R. (2015). Global trends in antimicrobial use in food animals. Proceedings of the National Academy of Sciences, 112 (18), 56495654. doi: 10.1073/pnas.1503141112

Wichmann, F., Udikovic-Kolic, N., Andrew, S., \& Handelsman, J. (2014). Diverse antibiotic resistance genes in dairy cow manure. MBio, 5(2), e01017-13. doi: 10.1128/mBio. 01017-13

Wright, G. D. (2007). The antibiotic resistome: the nexus of chemical and genetic diversity. Nature Reviews Microbiology, 5(3), 175. doi: 10.1038/nrmicro1614

Xie, W. Y., Shen, Q., \& Zhao, F. J. (2018). Antibiotics and antibiotic resistance from animalmanures to soil: a review. European Journal of Soil Science, 69(1), 181-195. doi: 10.1111/ejss.12494

Zhu, Y., Johnson, T., Su, J., Qiao, M., Guo, G., Stedtfeld, R., Tiedje, J. M. (2013). Diverse and abundant antibiotic resistance genes in Chinese swine farms. Proceedings of the National Academy of Sciences, 110(9), 3435-3440. doi: 10.1073/pnas.12 22743110 